EWA M. SUWARA

ORCID: 0000-0001-7724-2620

e-mail: ewamsuwara@gmail.com

\title{
"I did it my way"
}

Czy to koniec współpracy Zjednoczonego Królestwa i Unii Europejskiej w sprawach zagranicznych, bezpieczeństwai obrony?

\section{"I did it my way"}

Is it the end for the cooperation between the United Kingdom and the European Union in foreign affairs, security and defence?

\section{Słowa kluczowe:}

art. 50 TUE, BREXIT, WPBiO, WPZiB, negocjacje brexitowe, polityka zagraniczna, bezpieczeństwa i obrony
Keywords:

article 50 TEU, BREXIT, CFSP, CSDP, BREXIT negotiations, foreign and security policy 
"I did it my way".

Is it the end for the cooperation between the United Kingdom and the European Union in foreign affairs, security and defence?

31 December 2020 marks end of the "transition period" indicated in the Agreement on the Withdrawal of the United Kingdom from the European Union. Until the end of this period, the subject of future cooperation in foreign affairs, security and defence has not been negotiated within the BREXIT negotiations. It results in lack of its elaboration in a form of a written agreement on future relations between both Parties in this area. The main objective of this publication is to discuss cooperation between the United Kingdom and the EU in foreign affairs, security and defence as of 1 January 2021, following the end of "transition period" stipulated in the Agreement, considering that it has not been negotiated between the Parties. In this publication, the author discusses negotiation strategy adopted by the United Kingdom, the EU proposal of regulating future relations in foreign affairs, defence and security, as well as presents the forms of cooperation with third states applied so far by the EU. The publication indicates the impact of the BREXIT for the future cooperation in foreign affairs, defence and security. The author argues that the strategy of negotiation adopted by the United Kingdom on future cooperation in the foreign affairs, defence and security was well planned, and does not constitute an obstacle for deepening the future relations between the United Kingdom and the EU. 
And now, the end is near

And so I face the final curtain

My friends, I'll say it clear I'll state my case of which I'm certain

I've lived a life that's full

I traveled each and every highway

But more, much more than this

I did it my way.

Frank Sinatra My way (1968)

\section{Wstęp'}

31 grudnia 2020 roku zakończył się „okres przejściowy”, wskazany w Umowie o wystąpieniu Zjednoczonego Królestwa Wielkiej Brytanii i Północnej Irlandii (dalej: Zjednoczone Królestwo) z Unii Europejskiej (dalej UE) $)^{2}$. Od 1 lutego 2020 roku, tj. od dnia, gdy Umowa weszła w życie, strony miały czas na przyjęcie mandatów negocjacyjnych, pertraktacje dotyczące przyszłych relacji i wprowadzenie w życie nowych uzgodnień, obowiązujących od 1 stycznia 2021 roku. To przewidywała podpisana przez UE i Zjednoczone Królestwo Umowa. W odniesieniu do polityki zagranicznej i bezpieczeństwa dokument przewidywał także skrócenie okresu przejściowego w sytuacji, ǵdyby doszło do osiągnięcia porozumienia między stronami ${ }^{3}$.

Mimo pandemii coviD-19 główni negocjatorzy prowadzili rundy negocjacyjne, ale temat polityki zagranicznej, bezpieczeństwa i obrony nie był

1 W niniejszym artykule autorka prezentuje swoje prywatne opinie, niemające związku z oficjalnymi stanowiskami instytucji, z którymi jest zawodowo związana.

2 Umowa o wystąpieniu Zjednoczonego Królestwa Wielkiej Brytanii i Irlandii Północnej z Unii Europejskiej i Europejskiej Wspólnoty Energii Atomowej, Dz.U. UE (2019/C 384 I/1) 12 listopada 2019 roku, dostępna w internecie [dostęp: 5 XII 2020]: 〈https://eur-lex.europa.eu/legal-content/PL/TXT/?uri=CELEX:12020W/TXT〉.

3 „W przypadku osiągnięcia przez Unię i Zjednoczone Królestwo porozumienia w sprawie umowy dotyczącej ich przyszłych stosunków w dziedzinie wspólnej polityki zagranicznej i bezpieczeństwa oraz wspólnej polityki bezpieczeństwa i obrony, której stosowanie rozpocznie się w trakcie okresu przejściowego, tytuł v rozdział 2 TUE oraz akty przyjęte na podstawie tych postanowień przestają mieć zastosowanie do Zjednoczonego Królestwa od daty rozpoczęcia stosowania takiej umowy". Art. 127.2 Umowy o wystąpieniu Zjednoczonego Królestwa... 
$\mathrm{w}$ ich trakcie poddany dyskusji. W czerwcu 2020 roku Michel Barnier, główny negocjator ds. brexitu po stronie UE, stwierdził nawet: „Na koniec proszę pozwolić, że przypomnę, że od początku negocjacji Zjednoczone Królestwo odmawia rozmów o naszej przyszłej współpracy w obszarze polityki zagranicznej, rozwojowej i obrony, chociaż inaczej uzgodniliśmy to z Borisem Johnsonem w Deklaracji Politycznej. Prawdę mówiąc - jako były minister spraw zagranicznych - nadal nie rozumiem dlaczego"4 ${ }^{\prime 4}$. Do końca okresu przejściowego temat przyszłej współpracy w sprawach zagranicznych, bezpieczeństwa i obrony nie był negocjowany 5 .

24 grudnia 2020 roku Unia Europejska i Zjednoczone Królestwo poinformowały o uzgodnieniu umowy handlowej ${ }^{6}$. Nie reguluje ona przyszłych relacji w obszarze spraw zagranicznych, bezpieczeństwa i obrony. Oprócz wspomnianej umowy, 26 grudnia 2020 roku Unia Europejska i Zjednoczone Królestwo opublikowały także porozumienie o współ-

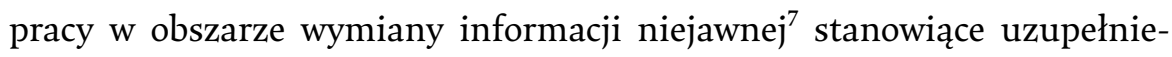
nie umowy handlowej ${ }^{8} \mathrm{i}$ będące podstawą dla dalszej współpracy w tym obszarze. Dodatkowo, 26 grudnia 2020 roku Europejska Wspólnota Energii

4 "Finally, let me remind you that, since the beginning of these negotiations, the UK refused to talk about our cooperation on foreign policy, development and defence, even though we agreed this with Boris Johnson in the Political Declaration. To tell the truth - as a former Minister for Foreign Affairs in my own country I still don't understand why". Statement by Michel Barnier, following Round 4 of negotiations for a new partnership between the European Union and the United Kingdom, 5 VI 2020, dostępny w internecie [dostęp: 9 XII 2020]: <https://ec.europa.eu/commission/presscorner/detail/en/speech_20_1017>.

5 Nieformalna rozmowa autorki z dyplomatami biorącymi udział w negocjacjach nad brexitem. Archiwum autorki.

6 Informacja dostępna na stronie Komisji Europejskiej [dostęp: 30 XII 2020]: <https:// ec.europa.eu/info/european-union-and-united-kingdom-forging-new-partnerhip/ future-partnership/draft-eu-uk-trade-and-cooperation-agreement_en $\rangle$.

7 Informacja dostępna na stronie Komisji Europejskiej [dostęp: 30 XII 2020]: <https:// ec.europa.eu/info/european-union-and-united-kingdom-forging-new-partnerhip/ future-partnership/draft-eu-uk-trade-and-cooperation-agreement_en>.

8 "Acknowledging that this Agreement constitutes a supplementing agreement to the Cooperation Agreement between the European Union and the European Atomic Energy Community of the one part, and the United Kingdom of Great Britain and Northern Ireland, of the other part (hereinafter Trade and Cooperation Agreement)". Preambuła Porozumienia między Unią Europejską a Zjednoczonym Królestwem dotyczącego procedur bezpieczeństwa dla wymiany 
Atomowej (EURATOM) i Zjednoczone Królestwo opublikowały uzgodnione porozumienie o cywilnej współpracy przy bezpiecznym i pokojowym użyciu energii atomowej ${ }^{9}$. Zapewnia ono ramy dla handlu technologią i materiałami nuklearnymi, ułatwia badania naukowe i rozwój oraz umożliwia $\mathrm{w}$ przyszłości wymianę informacji i ekspertyzy ${ }^{10}$.

Głównym celem niniejszego artykułu jest omówienie relacji między Zjednoczonym Królestwem a UE w obszarze spraw zagranicznych, bezpieczeństwa i obrony począwszy od 1 stycznia 2021 roku, tj. po zakończeniu okresu przejściowego wskazanego w Umowie o wystąpieniu Zjednoczonego Królestwa z UE, uwzględniając to, że nie stanowiły one przedmiotu pogłębionych negocjacji. W artykule autorka podejmie próbę odpowiedzi na następujące pytania:

- Co było powodem odmowy negocjowania przez Zjednoczone Królestwo kształtu przyszłych relacji w obszarze spraw zagranicznych, bezpieczeństwa i obrony?

- Czy współpraca między Zjednoczonym Królestwem i UE w obszarze spraw zagranicznych, bezpieczeństwa i obrony jest możliwa mimo że nie była przedmiotem ustaleń w okresie przejściowym - jeśli tak, to na jakich podstawach i w jakiej formule?

Udzielenie odpowiedzi na powyższe pytania, a więc zrozumienie badanego zagadnienia, wymaga odniesienia się do:

- relacji Zjednoczonego Królestwa i UE w sprawach zagranicznych, bezpieczeństwa i obrony $\mathrm{w}$ okresie przejściowym i ich ram przewidzianych w Umowie o wystąpieniu Zjednoczonego Królestwa z UE;

- strategii Zjednoczonego Królestwa w negocjacjach jego przyszłych relacji z UE w sprawach zagranicznych, bezpieczeństwa i obrony;

i ochrony informacji niejawnych, dostępne w internecie [dostęp: 30 XII 2020]: 〈https://ec.europa.eu/info/files/eu-uk-security-information-agreement_en〉.

9 Porozumienie między Europejską Wspólnotą Eneróii Atomowej (EURATOM) i Zjednoczonym Królestwem o cywilnej współpracy przy bezpiecznym i pokojowym użyciu energii atomowej, dostępne w internecie [dostęp: 30 XII 2020]: 〈https://ec/europe.eu/info/files/eu-uk-civil-nuclear-agreement_en〉.

10 UK and Euratom sign Nuclear Cooperation Agreement, "World Nuclear News" [online], 29 XII 2020, dostępny w internecie [dostęp: 30 XII 2020]: <https://www. world-nuclear-news.org/Articles/UK-and-Euratom-sign-Nuclear-CooperationAgreement?feed=FullFeed $>$. 
- propozycji UE odnośnie do dalszej współpracy ze Zjednoczonym Królestwem w sprawach zagranicznych, bezpieczeństwa i obrony;

- dotychczasowych form współpracy UE z państwami trzecimi w sprawach zagranicznych, bezpieczeństwa i obrony;

- skutków brexitu dla współpracy w sprawach zagranicznych, bezpieczeństwa i obrony w przypadku Zjednoczonego Królestwa i UE.

Niniejszy artykuł nie omawia prowadzonych przez Zjednoczone Królestwo i UE negocjacji $\mathrm{w}$ sprawach społeczno-ekonomicznych ani ich rezultatu. Nie została tu także poruszona kwestia granicy z Irlandią. Artykuł nie analizuje treści umowy handlowej, którą UE i Zjednoczone Królestwo uzgodniły 24 grudnia br., tj. na kilka dni przed zakończeniem okresu przejściowego. Nie ulega jednakże wątpliwości, że relacje gospodarcze i społeczne mogą wpływać na przyszłą współpracę Zjednoczonego Królestwa i UE w sprawach zagranicznych, bezpieczeństwa i obrony.

Podczas analizy autorka wykorzystała informacje pochodzące ze źródeł jawnych o charakterze pierwotnym: tj. z treści deklaracji politycznych, wywiadów oraz dokumentów obowiązujących w relacjach między Zjednoczonym Królestwem a UE. W przeprowadzonej analizie wykorzystano także informacje pochodzące ze źródeł o charakterze wtórnym: mediów krajowych i zagranicznych, dostępnej literatury, a także wiedzę zdobytą przez autorkę w czasie wieloletniej pracy w Brukseli.

W artykule dominuje perspektywa postpozytywistyczna, przyjęta wobec omawianej rzeczywistości, rozumianej jako sieć wzajemnych powiązań, interpretacji, działań i zaniechań, w której zarówno idea, jak i materialne siły mają pewną moc sprawczą ${ }^{11}$. W tym ujęciu wystąpienie Zjednoczonego Królestwa z Unii Europejskiej nie stanowi jedynie procesu normatywnego, lecz wynika także ze względów społecznych i kulturowych, które stanowiły podstawę dla jego wszczęcia, stopniowego przeprowadzenia i zakończenia. Artykuł podejmuje próbę zinterpretowania i zrozumienia tego zjawiska, co w przyszłości może pozwolić na jego stopniowe wyjaśnienie.

11 R. Zięba, Teoria bezpieczeństwa, [w:] Teorie i podejścia badawcze w nauce o stosunkach międzynarodowych, red. R. Zięba, S. Bieleń, J. Zając, Wydawnictwo Wydziału Dziennikarstwa i Nauk Politycznych Uniwersytetu Warszawskiego, Warszawa 2015, s. 100. 


\section{Współpraca w sprawach zagranicznych, bezpieczeństwa i obrony w okresie przejściowym ustanowionym przez Umowę o wystąpieniu Zjednoczonego Królestwa z UE}

Omówienie współpracy między Zjednoczonym Królestwem a UE w okresie poprzedzającym 1 stycznia 2021 roku i jej ram jest istotne dla określenia stanu początkowego "nowych" relacji łączących obie strony od tej daty.

23 czerwca 2016 r. obywatele Wielkiej Brytanii zagłosowali za opuszczeniem Unii Europejskiej (UE). 29 marca 2017 r. Zjednoczone Królestwo oficjalnie poinformowało Radę Europejską o zamiarze wystąpienia z UE. 24 stycznia 2020 roku Unia Europejska podpisała Umowę o wystąpieniu Zjednoczonego Królestwa z UE ${ }^{12}$, a 29 stycznia 2020 roku Parlament Europejski zgodził się na nią ${ }^{13} \cdot 30$ stycznia 2020 roku państwa członkowskie w Radzie UE przyjęły w procedurze pisemnej decyzję o zawarciu Umowy o wystąpieniu Zjednoczonego Królestwa z UE, co umożliwiło jej wejście w życie 31 stycznia 2020 roku o północy czasu środkowoeuropejskiego (23:0o czasu brytyjskiego). Od tego momentu Wielka Brytania przestała być formalnie członkiem UE.

W okresie przejściowym, obowiązującym do końca 2020 roku (według czasu brytyjskiego do godz. 23:00, 31 grudnia 2020 roku), współpraca Zjednoczonego Królestwa z UE w sprawach zagranicznych, bezpieczeństwa i obrony odbywała się na szczególnych zasadach ${ }^{14}$. Prawo UE miało zastosowanie do Zjednoczonego Królestwa i na jego terytorium. Zgodnie z artykułem 127.3 Umowy o wystąpieniu wywoływało ono takie same skutki prawne w odniesieniu do Zjednoczonego Królestwa i w Zjednoczonym Królestwie,

12 Umowa o wystąpieniu Zjednoczonego Królestwa...

13 Komunikat prasowy Rady: Brexit: Rada przyjmuje decyzje o zawarciu umowy o wystapieniu, 30 I 2020, dostępny w internecie [dostęp: 5 XII 2020]: <https:// www.consilium.europa.eu/pl/press/press-releases/2020/o1/30/brexit-council-adoptsdecision-to-conclude-the-withdrawal-agreement/?utm_source=dsms-auto\&utm_ medium =email\&utm_campaign $=$ Brexit $\% 3 a+$ Rada + przyjmuje + decyzj $\% c 4 \% 99+$ o+zawarciu+umowy+o+wyst $\%$ c4\%85pieniu $>$.

14 Tematyka niniejszej publikacji obejmuje wyłącznie obszar spraw zagranicznych i polityki bezpieczeństwa i obrony. Okres przejściowy obowiązywania Umowy odnosił się do licznych obszarów współpracy między Zjednoczonym Królestwem i Unią Europejską. 
jakie wywołuje w Unii i w jej państwach członkowskich, oraz było stosowane zgodnie z ogólnymi zasadami mającymi zastosowanie w Unii ${ }^{15}$.

W okresie przejściowym wszelkie odniesienia do państw członkowskich w prawie Unii, w tym wdrażanym i stosowanym przez państwa członkowskie, rozumiano jako odniesienia obejmujące również Zjednoczone Królestwo (artykuł 127.6 Umowy o wystąpieniu), z wyjątkiem trzech przypadków: przepisów w sprawie stałej współpracy strukturalnej ustanowionej na mocy artykułu 42 TUE, dotyczących wymiany informacji i spraw kadrowych.

Od godz. 23:00 31 stycznia 2020 roku (a według czasu środkowoeuropejskiego od północy 1 lutego 2020 roku) Zjednoczone Królestwo, będąc państwem trzecim względem UE, nie uczestniczyło już w kształtowaniu unijnej polityki zagranicznej, bezpieczeństwa i obrony zgodnie z tzw. Nonparticipation principle ${ }^{16}$. Artykuł 128.5 Umowy o wystąpieniu przewidywał, że już od początku okresu przejściowego Wielka Brytania nie będzie brała udziału w spotkaniach roboczych UE. Przedstawiciele Zjednoczonego Królestwa nie uczestniczyli w posiedzeniach Rady ds. Zagranicznych, COREPER II, Komitetu Politycznego i Bezpieczeństwa i poszczególnych grup tematycznych, geograficznych i horyzontalnych z obszaru Wspólnej Polityki Zagranicznej i Bezpieczeństwa. Od tej zasady w Umowie wskazano kilka wyjątków ${ }^{17}$.

Zjednoczone Królestwo nie mogło głosować i nie miało prawa weta, ale mogło złożyć na ręce Wysokiego Przedstawiciela Unii do Spraw Zagranicznych i Polityki Bezpieczeństwa formalne oświadczenie, że z istotnych względów polityki krajowej nie będzie stosowało decyzji objętej zakresem tytułu V rozdziału 2 TUE przyjętej przez Radę w okresie przejściowym. W duchu wzajemnej solidarności Wielka Brytania miała powstrzymać się od wszelkich działań, które mogłyby być sprzeczne z działaniami Unii podejmowanymi na podstawie tej decyzji lub mogłyby je utrudnić (artykuł 129.6 Umowy o wystąpieniu).

W praktyce większość zmian w sposobie zaangażowania Zjednoczonego Królestwa w unijną politykę zagraniczną, bezpieczeństwa i obrony zapoczątkowano albo wprowadzono przed rozpoczęciem okresu przejściowego.

15 Artykuł 127.3. Umowy o wystąpieniu Zjednoczonego Królestwa...

16 Artykuł 7.1 Umowy o wystąpieniu Zjednoczonego Królestwa...

17 Por.: artykuły 34.1, 128.5, 129.2,130.3, 136.3d, 138.3, 152.2, 155.2 Umowy o wystąpieniu. Umowa o wystąpieniu Zjednoczonego Królestwa... 
W marcu 2018 roku Komisja Europejska poinformowała, że Zjednoczone Królestwo po efektywnym wystąpieniu z UE nie będzie mogło uczestniczyć w systemie nawigacji satelitarnej Galileo. Tę opinię powtórzył główny negocjator po stronie unijnej w maju 2018 roku $^{18}$. Po wstępnych zastrzeżeniach Wielka Brytania przyjęła tę informację do wiadomości ${ }^{19}$, potwierdzając, że nie będzie z tego systemu korzystać. W marcu 2019 roku Zjednoczone Królestwo przekazało dowództwo nad operacją EU NAVFOR Atalanta Hiszpanii, a siedzibę operacji przeniesiono do bazy hiszpańskiej marynarki wojennej Rota ${ }^{20}$. W czerwcu 2019 roku dokonano zmiany dowództwa operacji EUFOR ALTHEA w Bośni i Hercegowinie: brytyjskiego generała zastąpił austriacki ${ }^{21}$.

W trakcie trwania okresu przejściowego Zjednoczone Królestwo nie podpisało z UE ani ramowej umowy dotyczącej współpracy w obszarze spraw zagranicznych, bezpieczeństwa i obrony, ani szczegółowych umów w zakresie udziału Wielkiej Brytanii w misjach i operacjach prowadzonych przez UE, udziału w programach unijnych z obszaru bezpieczeństwa i obrony czy koordynacji stanowisk w sprawach zagranicznych i dialogu politycznego w kluczowych dla UE i dla Zjednoczonego Królestwa kwestiach.

18 Wystąpienie Michela Barniera w EU Institute for Security Studies w maju 2018 roku, dostępne w internecie [dostęp: 10 XII 2020]: <https://europa.eu/rapid/ press-release_SPEECH-18-3785_en.htm>.

19 Brexit: UK wants £1bn back from $\mathrm{EU}$ if it is excluded from Galileo, BBC [online], 24 V 2018, [dostęp: 10 XII 2020], dostępny w internecie: <https://www.bbc.com/ news/uk-politics-44232269>; D. Baffey, What is Galileo and why are the UK and EU arguing about it?, "The Guardian" [online], 25 V 2018, [dostęp: 10 XII 2020], dostępny w internecie: <https://www.theguardian.com/politics/2018/may/25/ what-is-galileo-and-why-are-the-uk-and-eu-arguing-about-it>; Post-Brexit UK won't use EU Galileo satellite system, British PM says, Deutsche Welle, 1 XII 2018 [dostęp: 10 XII 2020], dostępny w internecie: <https://www.dw.com/en/ post-brexit-uk-wont-use-eu-galileo-satellite-system-british-pm-says/a-46533333 $\rangle$.

20 EU NAVFOR OHQ starts its activities in Rota, EUNAVFOR, komunikat prasowy, 29 III 2019 [dostęp: 29 XI 2020], dostępny w internecie: <https://www.eunavfor.eu/ eu-navfor_ohq-starts-its-activities-in-rota/>.

21 Change of command ceremony held at Camp Butmir, komunikat prasowy, European Union Force in BiH, 26 VI 2019 [dostęp: 10 XII 2020], dostępny w internecie: <http:// www.euforbih.org/eufor/index.php/press-corner/press-statements/2519-changeof-command-ceremony-at-camp-butmir $>$. 
Deklaracja Polityczna precyzująca ramy dla przyszłych relacji UE ze Zjednoczonym Królestwem

Dokumentem precyzującym ramy przyszłych relacji UE ze Zjednoczonym Królestwem była (albo, jak ostatnie miesiące pokazały, raczej miała być) Deklaracja Polityczna opublikowana 31 stycznia $2020 \mathrm{roku}^{22}$. Stanowi ona załącznik do Umowy o wystąpieniu Zjednoczonego Królestwa ${ }^{23}$ i miała być wyznacznikiem, tj. swoistą „mapą drogową" (ang. roadmap) porządkującą negocjacje nad kształtem przyszłej współpracy między stronami. Jej pierwszy zarys udostępniono państwom członkowskim UE 14 listopada 2018 roku $^{24}$. W listopadzie 2018 roku po zatwierdzeniu Umowy o wystąpieniu i Deklaracji przez państwa członkowskie UE przekazano dokumenty do akceptacji przez Zjednoczone Królestwo. W pierwszej połowie 2019 roku brytyjski parlament trzykrotnie odrzucił pakiet zaproponowanych przez negocjatorów dokumentów. Dlatego, po kilkumiesięcznych pracach nad tekstem (zmianie premiera Zjednoczonego Królestwa w lipcu 2019 roku), 17 października 2019 roku Rada Europejska zatwierdziła uaktualnioną wersję Deklaracji wraz z Umową o wystąpieniu Zjednoczonego Królestwa. 12 listopada 2019 r. nastąpiła jej publikacja w dzienniku Urzędowym UE (Dz.U. UE CI 384L z 12 listopada 2019 r. $)^{25}$. Uzgodnioną w październiku 2019 r. deklarację opublikowano ponownie wraz z umową o wystąpieniu Zjednoczonego Królestwa w styczniu 2020 roku (Dz.U. UE C 34 z 31 stycznia 2020 r.) ${ }^{26}$.

22 Revised Political Declaration setting the framework for the future relationship between the European Union and the United Kingdom, Official Journal of the European Union (2020/C 34/01), 31 I 2020.

23 Artykuł 1. Revised Political Declaration...

24 Pierwszy zarys Deklaracji Politycznej udostępniony państwom członkowskim UE w listopadzie 2018 r., dostępny w internecie [dostęp: 13 IV 2021]: <https://ec.europa.eu/info/publications/outline-political-declaration-setting-out-frameworkfuture-relationship-between-european-union-and-united-kingdom-great-britainand-northern-ireland-agreed-negotiators-level-14-november-2018_hu>.

25 Deklaracja Polityczna (opublikowana w listopadzie 2019 r.). Dz.U. UE. C 384I z 12 listopada 2019 r., dostępna w internecie [dostęp: 13 IV 2021]: <https://eur-lex.europa.eu/legal-content/EN/TXT/?uri=uriserv\%3AOJ.CI.2019.384.01.0178.01. ENG\& toc $=0 J \% 3 \mathrm{AC} \% 3 \mathrm{~A} 2019 \% 3 \mathrm{~A} 384 \mathrm{I} \% 3 \mathrm{ATOC}>$.

26 Deklaracja Polityczna (opublikowana w styczniu 2020 r.), Dz.U. UE. C 34 z 31 stycznia 2020 r., dostępna w internecie [dostęp: 13 IV 2021]: <https://eur-lex.europa.eu/legal-content/EN/TXT/?uri=uriserv:OJ.C_.2020.034.01.0001.01.ENG\&toc=OJ:C:2020:034:TOC $>$. 
Zgodnie z jej treścią relacje UE ze Zjednoczonym Królestwem powinny być partnerskie, a współpraca „ścisła" ${ }^{\text {"27 }}$.Ze względu na bliskość geograficzną i wspólnotę wartości partnerstwo powinno być "tak bliskie, jak to tylko możliwe"28 i obejmować kwestie współpracy w zakresie m.in. bezpieczeństwa, obrony i polityki zagranicznej, co pozwoli na wspólne mierzenie się z zewnętrznymi zagrożeniami dla wartości i interesów, które obie strony podzielają ${ }^{29}$. Przyszłe partnerstwo mogłoby obejmować także obszary, które nie zostały określone w Deklaracji Politycznej ${ }^{30}$.

Deklaracja podkreślała, że każda ze stron ma kształtować i implementować politykę zagraniczną i bezpieczeństwa zgodnie ze swoimi strategicznymi interesami, porządkiem prawnym oraz mając na uwadze bezpieczeństwo ${ }^{31}$. Partnerstwo miało uwzględniać prowadzenie dialogu, konsultacji, koordynacji oraz wymianę informacji (punkt 13 ii Wytycznych Rady Europejskiej), przy jednoczesnym poszanowaniu autonomii decyzyjnej $\mathrm{UE}^{32}$.

Z uwagi na wyjątkowy kontekst dotychczasowej relacji Zjednoczonego Królestwa z UE partnerstwu powinny towarzyszyć wysokie ambicje ${ }^{33}$. Współpraca powinna mieć charakter nie tylko bilateralny, lecz także przebiegać na forach społeczności międzynarodowej, a więc wszędzie tam, gdzie obie strony podzielają wartości i interesy, szczególnie na forum ONZ i NATO ${ }^{34}$. Jak pokazały pierwsze tygodnie okresu przejściowego, Deklaracja Polityczna nie stanowiła dla Wielkiej Brytanii ani podstawy, ani nawet „mapy drogowej” dla negocjacji dotyczących przyszłej współpracy

27 Punkt 13 ii. Wytyczne Rady Europejskiej (art. 50) w sprawie ram przyszłych stosunków UE - Wielka Brytania. Dokument nr. EUCO XT 20001/18 z 23 marca 2018 roku. Dostępny w internecie [dostęp: 13 IV 2021]: 〈www.consilium.europa.eu〉.

28 Punkt 13 ii. Wytyczne Rady Europejskiej (art. 50) w sprawie ram przyszłych stosunków UE - Wielka Brytania...

29 Artykuł 90. Revised Political Declaration...

30 Artykuł 3. Revised Political Declaration...

31 Artykuł 92. Revised Political Declaration...

32 Wytyczne Rady Europejskiej (art. 50) w sprawie ram przyszłych stosunków UE Wielka Brytania... Zasada autonomii decyzyjnej UE oznacza w praktyce, że najpierw UE ustala wewnętrznie, pomiędzy państwami członkowskimi, swoje stanowisko, a następnie ewentualnie konsultuje je z państwem trzecim. Autonomia decyzyjna UE jest kluczową zasadą i została wielokrotnie powtórzona w dokumentach omawiających przyszłe relacje UE ze Zjednoczonym Królestwem.

33 Artykuł 5. Revised Political Declaration...

34 Artykuł 90. Revised Political Declaration... 
w sprawach zagranicznych, bezpieczeństwa i obrony ${ }^{35}$. Dla Londynu były to jedynie niewiążące wskazówki co do sposobu osiągnięcia porozumienia ${ }^{36}$.

Treść Deklaracji Politycznej, podpisanej przez obie strony, odzwierciedlała początkową wolę pogłłębienia współpracy w zakresie spraw zagranicznych, bezpieczeństwa i obrony. Jednakże spory w trakcie negocjacji nad umową o wystąpieniu, zmiany na stanowisku premiera i w atmosferze politycznej wewnątrz Zjednoczonego Królestwa oraz związane z tym dążenia do odzyskania brytyjskiej suwerenności, a także pandemia coviD-19, spowodowały, że kwestie polityki zagranicznej, bezpieczeństwa i obrony przestały być dla Zjednoczonego Królestwa priorytetem w ramach uzgodnień o przyszłych relacjach z UE ${ }^{37}$. Rząd Borisa Johnsona pominął ten obszar $\mathrm{w}$ trwających negocjacjach z UE, nadając uzgodnieniom w kwestiach gospodarczych i społecznych priorytetowe znaczenie.

\section{Zjednoczone Królestwo wobec przyszłej współpracy z UE w sprawach zagranicznych, bezpieczeństwa i obrony}

29 marca 2017 roku Wielka Brytania poinformowała o zamiarze wystąpienia z UE, tym samym uruchamiając procedurę z artykułu 50. Traktatu o UE, mającą charakter dobrowolny i jednostronny. Decyzję o jej wszczęciu podjęli obywatele Zjednoczonego Królestwa w referendum przeprowadzonym 23 czerwca 2016 roku. Chociaż sprawy zagraniczne, bezpieczeństwa i obrony nie odegrały znaczącej roli w kampanii przed samym referendum ${ }^{38}$, od początku wydawało się, że zarówno UE, jak i Zjednoczone Królestwo dążą do pogłłębionego partnerstwa $\mathrm{w}$ tym obszarze $\mathrm{e}^{39}$. Theresa May, ówczesna minister spraw wewnętrznych w konserwatywnym rządzie Davida

35 R. G. Whitman, Missing in action: The EU-UK foreign, security and defence policy relationship after Brexit, Wilfired Martens Centre for European Studies, "European View" 2020, vol. 19(2), s. 223.

36 R. G. Whitman, Missing in action: The EU_UK foreign, security and defence policy..., s. 223.

37 Task Force (S. Abrial, P. Westmacott et al.), Toward a future EU-UK relationship in foreign policy and defense, Atlantic Council Europe Center Report, February 2021, s. 1.

38 J. Wither, A secure brexit? UK security and defense and the decision to leave the European Union, George C. Marshall European Center For Security Studies, "Security Insights" 2017, no. 18, ss. 3-4, dostępny w internecie [dostęp: 13 III 2021]: <https://www.marshallcenter.org/sites/default/files/files/2019-10/SecurityInsights_18.pdf $\rangle$.

39 Task Force (S. Abrial, P. Westmacott et al.), Toward a future EU-UK relationship..., s. 4 
Camerona, przemawiając do konserwatystów w kwietniu 2016 roku, wskazała na znaczenie UE dla zapewnienia bezpieczeństwa, tym samym prezentując argumenty za pozostaniem Zjednoczonego Królestwa w UE ${ }^{40}$.

Równolegle, w trakcie kampanii referendalnej, prominentni zwolennicy brexitu - m.in. Boris Johnson, ówczesny burmistrz Londynu - w swoich wypowiedziach osłabiali znaczenie UE w zapewnieniu bezpieczeństwa, podkreślając, że głównym jego gwarantem pozostaje $\mathrm{NATO}^{41}$.

Działania probrexitowe wpłynęły na wynik przeprowadzonego w czerwcu 2016 roku referendum. Zaskoczył on zdecydowaną większość elity politycznej ( $75 \%$ parlamentarzystów opowiadało się za pozostaniem w UE), powodując kryzys polityczny i gospodarczy na Wyspach ${ }^{42}$. Skutkował on upadkiem rządu Davida Camerona i przejęciem władzy przez Theresę May.

W styczniu 2017 roku premier Theresa May w swojej pierwszej przemowie na temat planów dotyczących brexitu podkreśliła dążenie Zjednoczonego Królestwa do dalszej ścisłej współpracy z partnerami z UE w zakresie spraw zagranicznych, bezpieczeństwa i obrony, także $\mathrm{w}$ trakcie procedury wystąpienia $\mathrm{z} \mathrm{UE}^{43}$. W tym samym duchu przemawiała na Monachijskiej Konferencji Bezpieczeństwa w maju $2018 \mathrm{r}^{44}$.

40 "Remaining inside the European Union does make us more secure; it does make us more prosperous, and it does make us more influential beyond our shores". T. May, Przemowa na temat brexitu, 25 IV 2016, dostępna w internecie [dostęp: 13 III 2021]: <http://www.conservativehome.com/parliament/2016/04/theresa-mays-speech-on-Brexit-full-text.html $>$.

41 J. Wither, A secure brexit? UK security and defense..., s. 3.

42 J. Wither, A secure Brexit? UK security and defense..., s. 4.

43 T. May, Przemowa z 17 I 2017 r., dostępna w internecie [dostęp: 8 IV 2021]: <https:// time.com/4636141/theresa-may-brexit-speech-transcript/>.

44 "So as we leave the EU and forge a new path for ourselves in the world, the UK is just as committed to Europe's security in the future as we have been in the past. Europe's security is our security. [...] We need a partnership that respects both the decision-making autonomy of the European Union and the sovereignty of the United Kingdom. [...] So, there is no reason why we should not agree distinct arrangements for our foreign and defence policy cooperation in the time-limited implementation period, as the Commission has proposed. This would mean that key aspects of our future partnership in this area would already be effective from 2019". T. May, Przemowa na Konferencji Bezpieczeństwa w Monachium, 17 II 2018, dostępna w internecie [dostęp: 10 XII 2020]: 〈https://www.gov.uk/government/ speeches/pm-speech-at-munich-security-conference-17-february-2018 $\rangle$. 
W Future relationship policy paper przedstawionym w brytyjskim parlamencie w lipcu 2018 roku $^{45}$ wzywała do stworzenia ambitnego partnerstwa z UE, obejmującego politykę zagraniczną, bezpieczeństwo i politykę rozwojową.

Zmiana w dotychczasowym podejściu Zjednoczonego Królestwa do przyszłej współpracy z UE w obszarze polityki zagranicznej, bezpieczeństwa i obrony nastąpiła wraz z rezygnacją Theresy May ze stanowiska premiera ${ }^{46}$ po tym, jak parlament brytyjski kilkukrotnie odrzucił wynegocjowaną przez nią propozycję umowy wystąpienia $\mathrm{z} \mathrm{UE}^{47}$. Objęcie przez Borisa Johnsona stanowiska premiera Zjednoczonego Królestwa (24 lipca 2019 r.) skutkowało dążeniem do zmiany uzgodnionej przez Theresę May Deklaracji Politycznej ${ }^{48}$. Nie odzwierciedlała ona poglądów Borisa Johnsona co do roli UE na arenie międzynarodowej i w zapewnieniu bezpieczeństwa $^{49}$. Naciskał on na uwzględnienie w treści Deklaracji potrzeby poszanowania autonomii decyzyjnej Zjednoczonego Królestwa. Takie sformułowania znalazły się w Deklaracji opublikowanej w listopadzie 2019 roku $^{50}$, a następnie w styczniu 2020 r. Mimo to, gdy doszło do negocjowania treści umowy o przyszłych relacjach między UE a Zjednoczonym Królestwem, rząd Borisa Johnsona nie wyraził zainteresowania podjęciem negocjacji w obszarze spraw zagranicznych, bezpieczeństwa i obrony.

45 T.May, Future relationship policy paper, July 2018, dostępny w internecie [dostęp: 13 II 2021]: <https://www.gov.uk/government/publications/the-futurerelationship-between-the-united-kingdom-and-the-european-union $\rangle$.

46 I. Bond, Post-Brexit foreign, security and defence co-operation: We don't want to talk about it, Centre for European Reform, November 2020, s. 1, dostępny w internecie [dostęp: 30 III 2021]: <https://www.cer.eu/sites/default/files/pbrief_brexit_forpol_26.11.20.pdf $>$.

47 Task Force (S. Abrial, P. Westmacott et al.), Toward a future EU-UK relationship..., s. 4.

48 S. Lehne, Rivals or partners? The EU-UK foreign policy relationship after brexit, Carnegie Europe, 30 III 2021 [dostęp: 30 III 2021]: dostępny w internecie: $<$ https:// carnegieeurope.eu/2021/03/3o/rivals-or-partners-eu-uk-foreign-policy-relationshipafter-brexit-pub-84197>.

49 S. Lehne, Rivals or partners?...

50 Institute for Government, Brexit deal: Political Declaration on future UK-EU relationship. Dokument wyjaśniający zmiany między oryginalnym tekstem z listopada 2018 (negocjowanym przez T. May) a tekstem z października 2019 r., dostępny w internecie [dostęp: 14 IV 2021]: 〈https://www.instituteforgovernment.org.uk/ explainers/brexit-deal-political-declaration $>$. 
W dokumencie opublikowanym 27 lutego 2020 roku, a więc tuż przed rozpoczęciem pierwszej rundy negocjacji ${ }^{51}$, Zjednoczone Królestwo poinformowało, że współpraca z UE w sprawach zagranicznych i podobnych jest ważna, ale nie wymaga stworzenia dla niej ram instytucjonalnych ${ }^{52}$. W praktyce słowa te ze strony Wielkiej Brytanii wyrażały brak chęci negocjowania przyszłej współpracy w sprawach zagranicznych, bezpieczeństwa i obrony przed końcem 2020 roku. Tekst dokumentu, poza fragmentami o udziale Zjednoczonego Królestwa w programach unijnych (s. 23), umowie o współpracy nuklearnej (s. 24) oraz umowie o wymianie informacji (s. 28), nie wykazywał woli Zjednoczonego Królestwa podjęcia negocjacji traktatu w odniesieniu do współpracy w zakresie bezpieczeństwa i obrony ${ }^{53}$.

Sztywna postawa negocjacyjna UE w rozmowach nad kształtem umowy o wystąpieniu z UE, szczególnie jeśli chodzi o ograniczenie dostępu Zjednoczonego Królestwa do programu Gallileo osłabiła pozycję brytyjskich zwolenników głębszego partnerstwa z UE ${ }^{54}$, co jednocześnie wzmocniło głosy na rzecz odejścia od rozmów o współpracy w sprawach zagranicznych, bezpieczeństwa i obrony. Zamiast dyskusji nad współpracą z UE rozpoczęto w Londynie rozmowy o globalnej roli Zjednoczonego Królestwa i jego sieci powiązań z państwami trzecimi. Ten kierunek myślenia stał się dominującym i skutkował kilkoma wydarzeniami pod koniec 2020 roku i na początku 2021 roku.

Podpisaniu umowy handlowej między UE a Wielką Brytanią 24 grudnia 2020 roku nie towarzyszyły formalne uzgodnienia względem przyszłej

51 Pierwsza runda odbyła się w dniach 2-5 marca 2020 r. Szczegóły dotyczące negocjacji dostępne są na stronie Komisji Europejskiej [dostęp: 10 XII 2020]: <https:// ec.europa.eu/info/european-union-and-united-kingdom-forging-new-partnership/ future-partnership/negotiation-rounds-future-partnership-between-europeanunion-and-united-kingdom_en>.

52 "Many policy areas - for example foreign policy or immigration policy are for the UK Government to determine, within a framework of a broader friendly dialogue and cooperation between the UK and the EU: they do not require an institutionalized relations". Our approach to the future relationship with the EU, Prime Minister's Office, 27 II 2020, pkt. 8, s. 4, dostępny w internecie [dostęp: 11 XII 2020]: <https://www.gov.uk/government/publications/ourapproach-to-the-future-relationship-with-the-eu $>$.

53 Our approach to the future relationship with the EU...

54 Task Force (S. Abrial, P. Westmacott i in.), Toward a future EU-UK relationship..., s. 5. 
współpracy w sprawach zagranicznych, bezpieczeństwa i obrony, na co zwrócono uwagę w komunikacie prasowym Komisji Europejskiej ${ }^{55}$. Wyjątek stanowi Porozumienie między Unią Europejską a Zjednoczonym Królestwem dotyczące procedur bezpieczeństwa dla wymiany i ochrony informacji niejawnych, podpisane przy okazji umowy handlowej i stanowiące do niej aneks ${ }^{56}$.

Utrzymując dotychczasowe stanowisko $\mathrm{w}$ kwestii wystąpienia z UE, w czasie Monachijskiej Konferencji Bezpieczeństwa, która odbyła się 19 lutego 2021 roku, premier Johnson wskazał, że dzięki brexitowi Zjednoczone Królestwo odbudowało suwerenność w sprawach zagranicznych, polityce bezpieczeństwa i obrony ${ }^{57}$.

W marcu 2021 roku rząd premiera Johnsona opublikował zapowiadany od kilkunastu miesięcy zintegrowany przegląd bezpieczeństwa, obrony, polityki rozwojowej i spraw zagranicznych ${ }^{58}$. W dokumencie nie omówiono planów dotyczących przyszłej współpracy z Unią Europejską, wskazując jedynie na znaczenie współdziałania z poszczególnymi członkami $\mathrm{UE}^{59}$.

55 „Foreign policy, external security and defence cooperation is not covered by the Agreement as the UK did not want to negotiate this matter. As of 1 January 2021, there will therefore be no framework in place between the UK and the EU to develop and coordinate joint responses to foreign policy challenges, for instance the imposition of sanctions on third country nationals or economies". Komunikat prasowy Komisji Europejskiej z 24 grudnia 2020 roku, dostępny w internecie [dostęp: 16 III 2021]: 〈https://ec.europa.eu/commission/presscorner/detail/en/ip_20_2531〉.

56 Porozumienie między Unią Europejska a Zjednoczonym Królestwem dotyczące procedur bezpieczeństwa dla wymiany $i$ ochrony informacji niejawnych...

57 „In leaving the European Union we restored sovereign control over vital levers of foreign policy". B. Johnson, Przemowa na Konferencji Bezpieczeństwa w Monachium 19 lutego 2021 r., dostępna w internecie [dostęp: 14 IV 2021]: <https://www.gov.uk/government/speeches/prime-ministers-speechat-the-munich-security-conference-19-february-2021>.

58 Global Britain in a competitive age. The Integrated Review of Security, Defence, Development and Foreign Security, HM Government, March 2021, dostępny na stronie [dostęp: 14 IV 2021]: 〈https://www.gov.uk>, Defence in a competitive age, HM Government, March 2021, dostępny w internecie [dostęp: 14 IV 2021]: <https://www. gov.uk>.

59 „As a European nation, we will enjoy constructive and productive relationships with our neighbours in the European Union, based on mutual respect for 
Brak szczegółowych odniesień do współpracy z UE w tym dokumencie nie musi prowadzić do zaprzestania dalszej współpracy z UE, podobnie jak wyżej omówione wydarzenia nie muszą wskazywać na niechęć Zjednoczonego Królestwa względem UE. Współpraca w obszarze spraw zagranicznych, bezpieczeństwa i obrony na arenie międzynarodowej ma głównie charakter symboliczny i może być sformalizowana ad hoc przez wprowadzenie $\mathrm{w}$ życie pojedynczych instrumentów (np. wspólnej deklaracji, jednomyślnego głosowania czy zastosowania zbieżnych środków restrykcyjnych). Nie wymaga trwałych ram prawnych i jest warunkowana m.in. przedmiotem negocjacji, kierunkiem rozwoju sytuacji oraz szeregiem innych czynników (w tym m.in. interesami narodowymi czy listą uczestniczących państw).

\section{Unijna propozycja umowy regulującej dalszą współpracę UE ze Zjednoczonym Królestwem}

UE od początku była zainteresowana prowadzeniem negocjacji nad przyszłymi relacjami ze Zjednoczonym Królestwem w obszarze spraw zagranicznych, bezpieczeństwa i obrony. To zainteresowanie było motywowane chęcią osłabienia negatywnych skutków wystąpienia Zjednoczonego Królestwa z UE przy jednoczesnym wzmocnieniu przekazu zewnętrznego o kontynuacji wspólnoty interesów na arenie międzynarodowej ${ }^{60}$. Jednakowe postrzeganie zagrożeń i zbliżone metody reagowania na nie, współpraca transatlantycka, bliskość geograficzna miały stanowić spoiwo łączące UE ze Zjednoczonymi Królestwem.

Ponadto z perspektywy UE podpisanie umowy formalizującej relacje w przyszłości miało być także formą zapobiegania dążeniom Zjednoczonego Królestwa do intensyfikacji kontaktów z członkami UE w formułach bilateralnych i w małych grupach (np. E3 z Francją i Niemcami) ${ }^{61}$. Działania

sovereignty and the UK's freedom to do things differently, economically and politically, where that suits our interests", Global Britain in a competitive age..., s. 13.

60 S. Lehne, Rivals or partners?..., s. 5-6.

61 W czasie przemówienia na tegorocznej konferencji w Monachium to właśnie o oczekiwaniach względem tej formuły współpracy premier Johnson wspominał najczęściej. B. Johnson, Przemowa na Konferencji Bezpieczeństwa w Monachium 19 lutego $2021 \mathrm{r} .$. 
te, w perspektywie krótko- i długoterminowej mogłyby negatywnie wpłynąć na wewnętrzną jedność unijną i prowadzić do osłabienia UE na arenie międzynarodowej.

Mimo wyraźnych syǵnałów ze strony rządu premiera Johnsona o braku zainteresowania nimi 18 marca 2020 roku UE opublikowała projekt umowy w sprawie Nowego Partnerstwa ze Zjednoczonym Królestwem ${ }^{62}$. Publikacja tekstu, w którym odniesiono się do kwestii dalszej współpracy w sprawach zagranicznych, bezpieczeństwa i obrony, nastąpiła, mimo że Wielka Brytania odmówiła prowadzenia negocjacji w tych obszarach. Treść projektu w znaczącym stopniu odzwierciedlała Deklarację Polityczną podpisaną przez UE i Zjednoczone Królestwo i była kolejną próbą UE organizacji przyszłej współpracy $\mathrm{w}$ tym obszarze. Zawierała ona propozycję ustanowienia dialogu politycznego i zinstytucjonalizowanej konsultacji $\mathrm{w}$ odniesieniu do spraw zagranicznych, bezpieczeństwa i obrony ${ }^{63}$. Przewidywała także prowadzenie regularnych dialogów tematycznych w sprawach o dużym znaczeniu dla obu stron w zakresie polityki zagranicznej. Proponowała współpracę UE ze Zjednoczonym Królestwem w kwestiach polityki sankcyjnej i promocji pokoju i stabilności oraz wymianę informacji, w tym także wywiadowczych, rozwoju zdolności obronnych, dalszej współpracy konsularnej, rozwojowej i w odniesieniu do przestrzeni kosmicznej. Projekt precyzował także kwestię udziału Wielkiej Brytanii w unijnych misjach i operacjach ${ }^{64}$.

Publikując projekt, UE umożliwiła Zjednoczonemu Królestwu poznanie jej podejścia w kwestii dalszej współpracy w sprawach zagranicznych, bezpieczeństwa i obrony i sposobu jej uregulowania. To jednakże nie wpłynęło w żaden sposób na taktykę Londynu.

62 European Commission's Task Force for Relations with the United Kingdom, Foreign, security and defence part of the draft text of the agreement on the new partnership with the United Kingdom, Document UKTF/2020/15, 18 III 2020, dostępny w internecie [dostęp: 10 XII 2020]: 〈https://europa.eu/!NH76fY〉.

63 European Commission's Task Force for Relations with the United Kingdom, Foreign, security and defence part of the draft text of the agreement on the new partnership with the United Kingdom...

64 European Commission's Task Force for Relations with the United Kingdom, Foreign, security and defence part of the draft text of the agreement on the new partnership with the United Kingdom... 


\section{Formy współpracy między UE a państwami trzecimi w sprawach} zagranicznych, bezpieczeństwa i obrony

Będąc państwem trzecim względem Unii, Zjednoczone Królestwo nie uczestniczy bezpośrednio w podejmowaniu decyzji na forum UE (EU decision-making). Od 2021 roku może ono jednakże uczestniczyć w wywieraniu wpływu na ten proces (EU decision-shaping). Z dotychczasowej praktyki wynika, że współpraca z UE w sprawach zagranicznych, bezpieczeństwa i obrony może przybrać różne formy, od nieformalnej do uregulowanej umową. Poniżej przedstawiono zarys głównych odmian współpracy, które mogą różnić się $\mathrm{w}$ detalach lub mogą zachodzić równolegle (np. dostosowanie do stanowiska UE wraz $\mathrm{z}$ podpisaną umową o Partnerstwie Strategicznym).

\section{- Dostosowanie do stanowiska UE (alignment with the EU)}

Ten typ współpracy dominuje w relacjach z państwami Europejskiego Obszaru Gospodarczego (EOG), Europejskiego Obszaru Wolnego Handlu (EFTA $)^{65}$ oraz państwami kandydującymi i aspirującymi do członkostwa. UE może poprosić te państwa o dostosowanie ich stanowisk do deklaracji unijnych, wypowiedzi UE bądź jej decyzji na forum organizacji międzynarodowych. Mechanizm dostosowania pozwala umocnić pozycję UE względem innych aktorów międzynarodowych, jednocześnie umożliwiając państwom trzecim potwierdzenie ich zbieżności z politycznymi wartościami i standardami, które wspiera UE. Ma on jedynie charakter polityczny i nie rodzi konsekwencji dla procesu podejmowania przez UE decyzji.

Ta formuła współpracy jest szczególnie ważna dla państw, które dążą do wstąpienia do $\mathrm{UE}^{66}$. Co do zasady państwa kandydujące i aspirujące mogą dokonywać wyborów i podejmować własne decyzje, jednakże w chwili wstąpienia na drogę ku akcesji do UE stają się tzw. active norm-takers, co związane jest ze zwiększoną potrzebą dostosowywania ich stanowisk do polityki UE w obszarze spraw międzynarodowych i bezpieczeństwa ${ }^{67}$. Warunek przyjęcia dorobku wspólnotowego i jego efektywna implementacja stanowi

65 W EOG są: Norwegia, Islandia i Lichtenstein. Do Europejskiego Obszaru Wolnego Handlu należą: Norwegia, Islandia, Lichtenstein oraz Szwajcaria.

66 Ch. Hillion, Adaptation for autonomy? Candidates for EU membership and the CFSP, "Global Affairs" 2017, vol. 3, issue 3.

67 Ch. Hillion, Adaptation for autonomy?... 
element ram negocjacyjnych przyjmowanych w procedurze przedakcesyjnej przez państwa zainteresowane wstąpieniem do $\mathrm{UE}^{68}$. $\mathrm{Z}$ perspektywy Zjednoczonego Królestwa, przynajmniej na ten moment jako państwa, które właśnie wystąpiło z UE (i nie planuje do niej powrócić), dostosowanie do unijnego stanowiska może być korzystne dla podkreślenia wspólnoty wartości przy jednoczesnym zachowaniu odrębności podmiotowej na arenie międzynarodowej i brytyjskiej autonomii decyzyjnej. Ma więc bardziej symboliczny wymiar. Wybierając tę formę współpracy, Zjednoczone Królestwo nie wpływa na przyjęte już przez UE stanowisko.

\section{- Wzmocnione dostosowanie do stanowiska UE (alignment +)}

Tę formę współpracy stosuje np. Norwegia, prowadząc z UE nieformalny dialog w sprawach zagranicznych, bezpieczeństwa i obrony ${ }^{69}$. Obie strony podzielają fundamentalne wartości i łączy je interes $\mathrm{w}$ znalezieniu wspólnych rozwiązań dla globalnych i regionalnych wyzwań ${ }^{70}$. By te cele osiągać, Norwegia prowadzi regularnie koordynację i konsultacje z Europejską Służbą Działań Zewnętrznych i z państwami członkowskimi na forum grup roboczych Rady. Szef rządu Norwegii regularnie spotyka się z Wysokim Przedstawicielem ds. Polityki Zagranicznej i Bezpieczeństwa ${ }^{71}$ na marginesie spotkań Rady Europejskiego Obszaru Gospodarczego ${ }^{72}$. Współpraca dotyczy wspólnych punktów zainteresowania, takich jak:

68 Ch. Hillion, Adaptation for autonomy?...

69 Chociaż Norwegia wskazuje w oficjalnych dokumentach, że dialog w obszarze spraw zagranicznych i bezpieczeństwa prowadzony jest na podstawie Umowy o Europejskim Obszarze Gospodarczym (EOG) należy zwrócić uwagę, że umowa ta nie odnosi się do spraw zagranicznych i bezpieczeństwa. Por.: Norway and the EU partners for Europe, Norwegian Ministry of Foreign Affairs, s. 14, dostępny w internecie [dostęp: 15 XII 2020]: <www.regjeringen.no/globalassets/departementene/ud/ vedleggeuropapolitikk/Norway_eu.pdf $\rangle$.

What is not covered by the EEA Agreement, EEA agreement pkt. 5, dostępny w internecie [dostęp: 15 XII 2020]: <https://www.efta.int/eea/eea-agreement/eea-basic-features $>$; jak i tekst samej umowy opublikowany w Dz.U. (L1) z 3 stycznia 1994, s. 3, z późn. zm., dostępny w internecie [dostęp: 15 XII 2020]: 〈http://www.efta. int?Legal-Text/EEA-Agreement-1327>.

70 Norway and the EU. Mission of Norway to the EU, dostępny w internecie [dostęp 11 XII 2020]: 〈www.norway.no〉.

71 Norway and the EU. Mission of Norway to the EU.

72 Norway and the EU - partners for Europe, Norwegian Ministry of Foreign Affairs, s. 14. 
Partnerstwo Wschodnie, pomoc rozwojowa, prawa człowieka, Europejska Polityka Sąsiedztwa, Bliski Wschód, walka z terroryzmem, zmiany klimatyczne, oBWE i Rada Europy ${ }^{73}$. Niszowa rola Norwegii w różnych międzynarodowych procesach pokojowych $\mathrm{w}$ połączeniu $\mathrm{z}$ dobrze dobranym systemem oddelegowania pracowników krajowych do Europejskiej Służby Działań Zewnętrznych jak i budżetem pozwalającym realizować różne działania o charakterze rozwojowym umożliwia jej wywieranie wpływu na UE w obszarach istotnych z perspektywy Oslo ${ }^{74}$.

- Nieformalne Partnerstwo Strategiczne (bez traktatu)

Ta forma współpracy dominuje w relacjach UE ze Stanami Zjednoczonymi Ameryki. Jej podstawą są: deklaracja transatlantycka z 1990 roku i nowa transatlantycka agenda partnerstwa z $1995 \mathrm{roku}^{75}$. USA i UE dotychczas nie podpisały umowy o strategicznym partnerstwie. Ich współpraca odbywa się $\mathrm{w}$ formie regularnych kontaktów o nieformalnym charakterze i poprzez formalne spotkania na poziomie władz USA, UE i państw członkowskich. To właśnie dzięki nieformalnym kontaktom na poziomie unijnym i bilateralnym USA może wpływać na UE ${ }^{76}$. W niektórych obszarach USA i UE podpisały szczegółowe umowy, takie jak: umowa w sprawie współpracy w obszarze zarządzania kryzysowego (2011), umowa o udziale USA w misji EULEX Kosowo (2007) czy bardziej ogólna umowa ramowa w sprawie udziału USA w misjach i operacjach wPBio (2011). Udział USA w misjach i operacjach ograniczony jest do oddelegowywania personelu cywilnego i zasobów cywilnych bez przekazania dowództwa nad siłami zbrojnymi, które tradycyjnie pozostaje w rękach władz amerykańskich ${ }^{77}$.

73 Norway and the EU. Mission of Norway to the EU.

74 I. Bond, British foreign policy after Brexit: hand in hand?, Centre for European Reform, CER Bulletin 2018, issue 119, s. 2.

75 D. S. Hamilton, US and EU Perspectives on their own dense, yet non-existent "Strategic Partnership", [w:] Strategic partnership as an instrument of EU foreign policy, Workshop Report, November 2015, s. 12, dostępny w internecie [dostęp: 11 XII 2020]: <http:// www.thomasrenard.eu/uploads/6/3/5/8/6358199/strategic-partnership-workshop-report-final.pdf>.

76 I. Bond, British foreign policy after Brexit: hand in hand?...

77 T. Tardy, CSDP: getting third states on board, European Union Institute for Security Studies, 7 III 2014, s. 2, dostępny w internecie [dostęp: 13 XII 2020]: <https://www. iss.europa.eu/content/csdp-getting-third-states-board $>$. 


\section{- Formalne partnerstwo strategiczne albo umowa ramowa na mocy art. 37 Traktatu o Unii Europejskiej}

Kanada, Japonia oraz Australia współpracują z UE w obszarze polityki zagranicznej, bezpieczeństwa i obrony w oparciu o traktat podpisany na mocy artykułu 37 Traktatu o Unii Europejskiej ${ }^{78}$. Zakres współpracy z tym państwami jest zróżnicowany.

Umowa ramowa podpisana z Australią w 2017 roku przewiduje współpracę w zakresie polityki zagranicznej i bezpieczeństwa, trwałego rozwoju, zmian klimatycznych i kwestii ekonomicznych i handlowych ${ }^{79}$.

W 2016 roku UE i Kanada podpisały umowę o partnerstwie strategicznym ${ }^{80}$. Wskazuje ona poziom i częstotliwość dialogów politycznych. Natomiast Umowa o Partnerstwie Strategicznym z Japonią, podpisana w 2018 roku, w większym stopniu mówi o obszarach współpracy niż o jej $\operatorname{metodach}^{81}$.

78 Artykuł 37 Traktatu o Unii Europejskiej stanowi, że “Unia może zawierać umowy z jednym lub z większą liczbą państw lub z organizacjami międzynarodowych w dziedzinach objętych niniejszym rozdziałem". Rozdział dotyczy polityki zagranicznej i bezpieczeństwa. Traktat o Unii Europejskiej (wersja skonsolidowana) opublikowany w Dz.U. UE (2016/C202/13) z 7 czerwca 2016 roku, dostępny w internecie [dostęp: 13 XII 2020]: <https://eur-lex.europa. eu/resource.html?uri=cellar:9e8d 52e1-2c70-11e6-b497-01aa75ed71a1.0018.01/ DOC_2\&format $=P D F>$.

79 Framework agreement between the European Union and Australia, dostępna w internecie [dostęp: 11 XII 2020]: 〈https://www.dfat.gov.au/geo/europe/european-union/ Pages/australia-european-union-eu-framework-agreement $>$; Decyzja Rady (UE 2017/1546 z dnia 29 września 2016 roku w sprawie podpisania, w imieniu Unii Europejskiej, i tymczasowego stosowania Umowy ramowej między Unią Europejską i jej państwami członkowskimi z jednej strony a Australią z drugiej, Dz.U. UE (2017/L237/5) z 15 września 2017 roku, dostępna w internecie [dostęp: 10 XII 2020]: 〈http://data.europa.eu/eli/dec/2017/1546/oj〉.

80 Także i ta umowa nadal podlega ratyfikacji przez państwa członkowskie UE. Dlatego obowiązuje tymczasowo w części, która pozostaje w kompetencjach Unii, w tym m.in. w zakresie polityki zagranicznej i bezpieczeństwa.

Notice concerning the provisional application of the Strategic Partnership Agreement between the European Union and its Member States of the one part and Canada of the other part, Dz.U. UE (2017/L89/60), 1 IV 2017, dostępny w internecie [dostęp: 10 XII 2020]: <https://www.consilium.europa.eu/en/documents-publications/treatiesagreements/agreement/?id=2016018\&DocLanguage $=$ en\# $>$.

81 Japan-EU Strategic Partnership Agreement, dostępna w internecie [dostęp: 10 XII 2020]: 〈https://www.mofa.go.jp/erp/ep/page22e_000707.html〉. 
Podpisane przez strony umowy nakładają na UE i jej partnerów wymóg prowadzenia regularnych konsultacji na różnych poziomach ekspertów $\mathrm{w}$ obszarach horyzontalnych i geograficznych przez nich uzgodnionych ${ }^{82}$.

Powyższe przykłady nie determinują ostatecznie możliwości w uzgodnieniach ram dla dalszej współpracy z państwami trzecimi. Podpisane umowy mogą skupiać się albo tylko na obszarach współpracy, albo na jej instytucjonalizacji, albo omawiają oba elementy w detalach. Relacje z państwami trzecimi mogą także nie mieć formalnych ram i mogą odbywać się na zasadzie dopasowywania formuły do potrzeb obu stron. Wyjątkiem jest udział państw trzecich w misjach i operacjach unijnych. Jest on zawsze regulowany odrębnymi umowami. One także są podpisywane na mocy artykułu 37 Traktatu o Unii Europejskiej ${ }^{83}$ i noszą nazwę umów o ramowym udziale (ang. Framework Participation Agreement - FPA) ${ }^{84}$. Według szacunkowych danych w misjach i operacjach WPBio dotychczas uczestniczyło 45 państw trzecich ${ }^{85}$. Umowy te zapewniają ramy prawne określające zarówno charakter sił, sposoby wymiany informacji, uczestnictwo w procesie podejmowania decyzji odnośnie do poszczególnych misji i operacji, jak i kwestie finansowego udziału państwa trzeciego.

Udział państw trzecich w unijnej polityce zagranicznej, bezpieczeństwa i obrony nie wpływa na autonomię decyzyjną UE. Zaproszenie państw trzecich do udziału w misji czy operacji następuje na późniejszym etapie planowania, bez ich zaangażowania $\mathrm{w}$ przygotowanie koncepcji operacji (CONOPS) czy planu operacji (OPLAN) i po podjęciu decyzji co do ostatecznego kształtu dokumentów w gronie państw członkowskich UE. Państwa trzecie uzyskują dostęp do informacji dotyczących misji czy operacji na podstawie zgody Komitetu Politycznego i Bezpieczeństwa. Nie biorą udziału w planowaniu naboru (ang. force generation conference). Muszą dostosować się do terminów i procedur wyznaczonych przez UE. Po ich dopuszczeniu do udziału w danej misji czy operacji zasiadają w komitecie (ang. Committee

82 I. Bond, British foreign policy after Brexit: hand in hand?...

83 F. Naert, The use of the CFSP legal basis for EU international agreements in combination with other legal bases, [w:] The EU as a global actor - bridging legal theory and practice, eds J. Czuczai, F. Naert, Brill NV 2017, s. 394-423.

84 O kwestii udziału państw trzecich we współpracy obronnej w ramach stałej współpracy strukturalnej autorka napisała szerzej w kolejnym podrozdziale artykułu.

85 T. Tardy, CSDP: getting third states on board..., s. 1. 
of Contributors), na forum którego następuje wymiana informacji i dyskusja o sprawach dotyczących danej misji czy operacji ${ }^{86}$.

Jak już zostało to podkreślone, Wielka Brytania jest de iure państwem trzecim. Jednakże żadne z państw trzecich, które współpracuje z UE w sprawach zagranicznych bezpieczeństwa i obrony, nigdy nie było członkiem UE. Doświadczenie wieloletniego członkostwa w Unii sprawia, że Zjednoczone Królestwo ma de facto szczególny status w relacjach z nią. Ta cecha może zrodzić szereg nieformalnych relacji z UE, które zastąpią potrzebę formalnych struktur zagwarantowanych traktatowo albo znacząco wzbogacić umowne formy uregulowania przyszłych stosunków z Unią. Kwestią czasu jest uregulowanie niektórych obszarów dalszej współpracy (np. udziału w misjach i operacjach).

\section{Skutki brexitu dla współpracy w sprawach zagranicznych, bezpieczeństwa i obrony}

Oprócz wielu dostępnych form współpracy z UE innym argumentem przemawiającym za brakiem pośpiechu $\mathrm{w}$ formalizowaniu relacji $\mathrm{z}$ UE jest konieczność „wygaszenia” negatywnych emocji związanych z zakończonymi negocjacjami nad umową o wyjściu Zjednoczonego Królestwa z UE. Przykładem takich negatywnych emocji było niedawno opublikowane stanowisko Londynu $\mathrm{w}$ sprawie uznania przedstawiciela UE za reprezentanta organizacji międzynarodowej, bez przyznania mu pełnego spektrum przywilejów i immunitetów, które należą się przedstawicielom państw ${ }^{87}$. Takie zachowanie spotkało się $\mathrm{w}$ styczniu br. $\mathrm{z}$ negatywną reakcją UE, która w zamian ograniczyła Brytyjczykom dostęp do instytucji unijnych. Skutkiem brexitu jest więc (czasowe?) ochłodzenie relacji, co może prowadzić do dalszego wzrostu napięcia na linii Londyn-Bruksela. By móc efektywnie współpracować, negatywne emocje powinny „wygasnąć".

86 Autorka w trakcie pracy w Brukseli wielokrotnie uczestniczyła w spotkaniach dotyczących funkcjonowania poszczególnych misji i operacji WPBio, które odbywały się w różnych formatach.

87 P. Wintour, D. Boffey, UK insists it will not grant eu ambassador full diplomatic status, "The Guardian" [online], 21 I 2021, dostępny w internecie [dostęp: 1 II 2021]: 〈https://www.theguardian.com/world/2021/jan/21/uk-insists-it-will-notgrant-eu-ambassador-full-diplomatic-status $>$. 
Krótko- i długoterminowo brexit może osłabić UE, dla której wyjście Wielkiej Brytanii oznacza utratę część potencjału gospodarczego, finansowego, naukowo-technicznego, politycznego oraz militarnego ${ }^{88}$.

Wystąpienie Zjednoczonego Królestwa z liczbą ludności 66 milionów wpłynie na relacje UE z państwami trzecimi. Może dojść do wzmocnienia współpracy z rejonami francuskojęzycznymi i zwiększenia zaangażowania UE na Południu. Dodatkowo Zjednoczone Królestwo może osłabić chęć wzmocnienia polityki UE względem Rosji i wzğlędem państw Partnerstwa Wschodniego. Wielka Brytania znana była z jej znaczącej aktywności, jeśli chodzi o politykę sankcyjną względem Rosjii ${ }^{89}$. Wewnątrz UE może to oznaczać konieczność budowania nowych koalicji państw podobnie myślących, by umacniać stanowisko względem Rosji w zamian za realizację innych interesów.

Ponadto UE traci możliwość korzystania z rozbudowanej sieci przedstawicielstw dyplomatycznych Zjednoczonego Królestwa ${ }^{90}$, co oznacza utratę dostępu do informacji pozostających w posiadaniu Wielkiej Brytanii i brak wsparcia z jego strony dla działań UE w terenie.

Tradycyjnie Zjednoczone Królestwo nie było postrzegane jako zwolennik wzmacniania WPBio ${ }^{91}$. Dlatego też brexit może stopniowo i permanentnie odblokować pewne tematy do dyskusji na forum Rady, takie jak budżet Europejskiej Agencji Obrony czy wspólne finansowanie misji $\mathrm{WPBiO}^{92}$, poprzez mechanizm Athena ${ }^{93}$. Niektórzy analitycy zwracają jednak uwagę, że kilka państw ukrywających się dotychczas za Zjednoczonym Królestwem podziela jego stanowisko i także przeciwstawia się bardziej formalnym

88 J. Fiszer, Perspektywy Unii Europejskiej po Brexicie i jej rola w nowym ładzie europejskim, Zakład Europeistyki, Instytut Studiów Politycznych PAN, „Biuletyn Analiz i Opinii" 2017, nr 04, s. 2.

89 R.Zięba, The Euro-Atlantic security system in the 21st century. From cooperation to crisis, Springer International Publishing, New York 2018, (Global Power Shift).

90 Obecnie Zjednoczone Królestwo ma około 270 takich przedstawicielstw, w tym konsularnych i handlowych. Por. Strona internetowa rządu brytyjskiego [dostęp: 10 XII 2020]: 〈www.gov.uk〉.

91 R. Zięba, The Euro-Atlantic security system in the $21^{\text {st }}$ century, s. 189.

92 A. Dumoulin, N. Gros-Verheyde, La politique europeene de securite et de defense commune, Editions du Villard Le Devoluy, Bruxelles 2017, s. 450.

93 J. Shea, European defence after brexit. A plus or a minus?, "European View" 2020, vol. 19, issue 1, ss. 88-94. 
zobowiązaniom w kwestii wspólnej obrony (np. Irlandia, Austria, Szwecja) ${ }^{94}$. Może to więc oznaczać, że wraz z wystąpieniem Zjednoczonego Królestwa będą one zmuszone do wyjścia „z ukrycia” - co w konsekwencji może nadal blokować dalszy rozwój w tym obszarze.

Zjednoczone Królestwo dysponuje znaczącym potencjałem militarnym, obejmującym siły specjalne, lotnictwo, marynarkę i służby wywiadowcze $^{95}$. Jest też potęgą nuklearną. Realizuje kryterium $2 \%$ PKB na budżet obronny, będąc drugim z kolei największym płatnikiem do budżetu NATO ${ }^{96}$. Wystąpienie Zjednoczonego Królestwa z UE jest więc przeszkodą dla bardziej efektywnego budowania unijnych sił zbrojnych, co oznacza zmniejszenie zdolności obronnych Unii i wyzwanie dla jej zdolności operacyjnych.

Wraz z wystąpieniem Zjednoczonego Królestwa z UE w relacjach dwustronnych przestaje istnieć obowiązek niesienia pomocy i wsparcia $\mathrm{w}$ razie ataku zbrojnego na terytorium UE na podstawie artykułu 42.7 Traktatu o UE oraz wsparcia w sytuacji zagrożenia atakiem terrorystycznym na mocy artykułu 222 Traktatu o Funkcjonowaniu UE.

Ponadto brexit będzie miał znaczący wpływ na przemysł obronny w Zjednoczonym Królestwie ${ }^{97}$. Pozostając poza wspólnym rynkiem, brytyjskie podmioty będą miały ograniczony dostęp do projektów UE i funduszy unijnych ${ }^{98}$. Od 1 stycznia 2021 roku Wielka Brytania nie

94 S. Lain, V Nouwens, The consequences of brexit for european defence and security, April 2017, s. 12, dostępny w internecie [dostęp: 2 II 2021]: < https://rusi.org/sites/default/ files/201704_o8_rusi-fes_brexit_defence_and_security_lain_and_nouwens.pdf $\rangle$.

95 Najnowsze szczegóły dotyczące wielkości sił wojskowych można znaleźć w UK Defence Personnel Statistics Briefing Paper, House of Commons Library 8 III 2021, dostępny w internecie [dostęp: 20 III 2021]: <https://commonslibrary.parliament. uk/research-briefings/cbp-7930/>.

96 T. May, Przemowa na Konferencji Bezpieczeństwa w Monachium 17 lutego 2018 roku, dostępna w internecie [dostęp: 10 XII 2020]: <https://www.gov.uk/government/ speeches/pm-speech-at-munich-security-conference-17-february-2018 $\rangle$.

97 M. Oleksiejuk, The impacts of Brexit on the security and the defence industry in the European Union and the United Kingdom, Warsaw Institute, 21 IV 2020, dostępny w internecie [dostęp: 10 XII 2020]: <https://warsawinstitute.org/ impacts-brexit-security-defence-industry-european-union-united-kingdom/ $>$.

98 G. Wright, UK-EU future relationship: Defence and security cooperation, The Institute for Government, 25 II 2020, dostępny w internecie [dostęp: 10 XII 2020]: $<$ https://www.instituteforgovernment.org.uk/explainers/future-relationshipdefence-security-cooperation $>$. 
uczestniczy w unijnym programie wsparcia, obserwacji i śledzenia obiektów kosmicznych, w Galileo czy EGNOs ${ }^{99}$. Porozumienie między Euratom i Zjednoczonym Królestwem o cywilnej współpracy przy bezpiecznym i pokojowym użyciu energii atomowej ${ }^{100}$, opublikowane 26 grudnia $2020 \mathrm{r}$. i podlegające procedurze ratyfikacji, będzie precyzować współpracę w tym obszarze.

Udział Zjednoczonego Królestwa w stałej współpracy strukturalnej (PESCO), ustanowionej na mocy artykułu 42 Traktatu o UE, jest możliwy warunkowo i wyjątkowo. Warunki polityczne, merytoryczne i prawne uczestnictwa państw trzecich w PESCO zostały doprecyzowane i uzgodnione przez Rade 5 listopada 2020 roku ${ }^{101}$. W praktyce, gdy państwo trzecie zơłosi chęć udziału w określonym projekcie PESCO, uczestnicy projektu będą musieli jednomyślnie stwierdzić, czy wniosek spełnia wszystkie warunki, oraz powiadomić o swoich ustaleniach Radę i Wysokiego Przedstawiciela ds. Polityki Zagranicznej i Bezpieczeństwa. Ostateczną decyzję podejmie Rada - co ponownie podkreśla zasadę autonomii strategicznej UE. Zjednoczone Królestwo też musi spełnić wszystkie warunki.

Mimo brexitu należy spodziewać się dalszej współpracy między Zjednoczonym Królestwem a UE na forum organizacji międzynarodowych, takich jak ONZ, OBWE, Rada Europy czy NATO. Współpraca ta jednak nie będzie tożsama $z$ dotychczasową. Brexit oznacza dla UE utratę jednego z dwóch miejsc permanentnych w Radzie Bezpieczeństwa Narodów Zjednoczonych, a dla Zjednoczonego Królestwa konieczność rozbudowania sieci pozyskiwania kontaktów i informacji, które umożliwią mu sprawniejsze działanie na arenie międzynarodowej zgodnie z zamysłem budowania "Global Britain"102.

99 European Geostationary Navigation Overlay Service, dostępny w internecie [dostęp: 13 XII 2020]: 〈www.gsa.europa.eu/egnos〉.

100 Porozumienie o cywilnej współpracy przy bezpiecznym i pokojowym użyciu energii atomowej...

101 Unijna wspólpraca obronna: Rada określa warunki uczestnictwa państw trzecich w PESCO, komunikat prasowy, $11 \mathrm{~V}$ 2020, dostępny w internecie [dostęp: 13 XII 2020]: <https://www.consilium.europa.eu/pl?press/press-releases?2020/11/05/ eu-defence-cooperation $>$.

102 D. Raab. Global Britain is leading the world as a force for good, "Sunday Telegraph", 23 IX 2019, dostępny w internecie [dostęp: 9 XII 2020]: 〈www.gov.uk〉. 


\section{Zakończenie}

Uwarunkowania wewnętrzne, ambicje rządu Zjednoczonego Królestwa oraz wydarzenia na świecie wpłynęły na ewolucję podejścia Londynu do dyskusji o przyszłej współpracy z UE w sprawach zagranicznych, bezpieczeństwa i obrony. Równolegle trwające i wymagające względem obu stron negocjacje w sprawach społeczno-gospodarczych stały się dla Londynu priorytetem. Kwestie te, w przeciwieństwie do spraw zagranicznych, bezpieczeństwa i obrony, wywierają bezpośredni wpływ na codzienne życie Brytyjczyków. Początkowe zainteresowanie pogłębieniem partnerstwa $\mathrm{z}$ UE $\mathrm{w}$ obszarze spraw zagranicznych, bezpieczeństwa i obrony zastąpiono dążeniem Londynu do umocnienia przekazu o chęci odzyskania utraconej brytyjskiej suwerenności i w konsekwencji do porzucenia idei pogłębienia współpracy poprzez wspólnie wypracowaną umowę ramową.

Brak uregulowania przyszłej współpracy z UE w sprawach zagranicznych, bezpieczeństwa i obrony przed końcem 2020 roku nie jest przeszkodą ani dla jej rozwinięcia, ani dla ewentualnego jej sformalizowania w nadchodzących miesiącach i latach. W perspektywie długoterminowej działania Zjednoczonego Królestwa i ich skutek nie powinny wpłynąć negatywnie na współpracę z UE w sprawach zagranicznych, bezpieczeństwa i obrony. Wielka Brytania jest dotychczas jedynym państwem trzecim, które wcześniej miało status członka UE. Oznacza to, że kształtowanie relacji w „nowej rzeczywistości” względem UE może albo przybrać różnorodne formy dotychczas stosowane przez Unię względem innych państw trzecich albo stworzyć nową podstawę dla pogłębienia tych relacji. W razie konieczności bądź perspektywy obopólnych korzyści może także skutkować znaczącym zacieśnieniem ich relacji, umożliwiając Zjednoczonemu Królestwu wykorzystanie wieloletnich doświadczeń z bycia państwem członkowskim UE dla podjęcia działania według jego własnych reguł.

\section{Bibliografia}

Baffey D., What is Galileo and why are the UK and EU arguing about it?, “The Guardian" [online], 25 V 2018 [dostęp: 10 XII 2020], dostępny w internecie: <https://www.theguardian.com/politics/2018/may/25/what-is-galileo-and-whyare-the-uk-and-eu-arguing-about-it $>$.

Bond I., British foreign policy after Brexit: hand in hand?, Centre for European Reform, CER Bulletin 2018, issue 119. 
Bond I., Post-Brexit foreign, security and defence co-operation: We don't want to talk about it. Centre for European Reform, November 2020, dostępny w internecie [dostęp: 30 III 2021]: <https://www.cer.eu/sites/default/files/pbrief_brexit_ forpol_26.11.20.pdf>.

Brexit deal: Political Declaration on future UK-EU relationship, Institute for Government, dostępny w internecie [dostęp: 14 IV 2021]: 〈https://www.instituteforgovernment.org.uk/explainers/brexit-deal-political-declaration $>$.

Brexit: Rada przyjmuje decyzje o zawarciu umowy o wystąieniu, komunikat prasowy, 30 I 2020, dostępny w internecie [dostęp: 13 XII 2020]: <https://www. consilium.europa.eu/pl/press/press-releases/2020/01/3o/brexit-council-adoptsdecision-to-conclude-the-withdrawal-agreement/?utm_source=dsms-auto\&utm_medium =email\&utm_campaign $=$ Brexit $\% 3 a+$ Rada + przyjmuje + decyz $\mathrm{j} \% \mathrm{c}_{4} \% 99+\mathrm{o}+\mathrm{zawarciu}+\mathrm{umowy}+\mathrm{o}+$ wyst $\% \mathrm{c4} \% 85$ pieniu $>$.

Brexit: UK wants £1bn back from $E U$ if it is excluded from Galileo, BBC [online], 24 V 2018, dostępny w internecie [dostęp: 10 XII 2020]: 〈https://www.bbc.com/ news/uk-politics-44232269>.

Decyzja Rady (UE 2017/1546 z dnia 29 września 2016 roku w sprawie podpisania, w imieniu Unii Europejskiej, i tymczasowego stosowania Umowy ramowej między Unią Europejską i jej państwami członkowskimi z jednej strony a Australią z drugiej, Dz.U. UE (2017/L237/5) z 15 września 2017 roku, dostępna w internecie [dostęp: 10 XII 2020]: 〈http:data.europa.eu/eli/dec/2017/1546/oj〉.

Defence in a competitive age, HM Government, March 2021, dostępny w internecie [dostęp: 14 IV 2021]: 〈https://www.gov.uk>.

Deklaracja Polityczna (opublikowana w listopadzie 2019 r.) Dz.U. UE C 384I z 12 listopada 2019 r., dostępna w internecie [dostęp: 13 IV 2021]: <https://eur-lex.europa.eu/legal-content/EN/TXT/?uri=uriserv\%3AOJ.CI.2019.384.01.0178.01. ENG\& toc $=$ OJ\%3AC $\% 3$ A2019\%3A384I\%3ATOC $>$.

Deklaracja Polityczna (opublikowana w styczniu 2020 r.), Dz.U. UE C 34 z 31 stycznia 2020 r., dostępna w internecie [dostęp: 13 IV 2021]: <https://eur-lex. europa.eu/legal-content/EN/TXT/?uri=uriserv:OJ.C_.2020.034.01.0001.01. ENG\&toc $=$ OJ:C:2020:034:TOC $>$.

Draft EU-UK trade and cooperation agreement, European Commission, dostępny w internecie [dostęp: 30 XII 2020]: <https://ec.europa.eu/info/european-unionand-united-kingdomforging-new-partnerhips/future-partnership/draft-eu-uktrade-and-cooperationagreement_en $>$.

Dumoulin A., Gros-Verheyde N., La politique europeene de securite et de defense commune, Editions du Villard Le Devoluy, Bruxelles 2017.

EU NAVFOR OHQ starts its activities in Rota, EUNAVFOR, komunikat prasowy, 29 III 2019, dostępny w internecie [dostęp: 29 XI 2020]: 〈https://www.eunavfor.eu/eu-navfor_ohq-starts-its-activities-in-rota $>$.

European Commission's Task Force for Relations with the United Kingdom, Foreign, Security and Defence Part of the Draft Text of the Agreement on the New 
Partnership with the United Kingdom, Document UKTF/2020/15, 18 III 2020, dostępny w internecie [dostęp: 10 XII 2020]: 〈https://europa.eu/!NH76fY>.

European Geostationary Navigation Overlay Service, dostępny w internecie [dostęp: 13 XII 2020]: 〈www.gsa.europa.eu/egnos〉.

Fiszer J., Perspektywy Unii Europejskiej po Brexicie $i$ jej rola $w$ nowym ładzie europejskim, Zakład Europeistyki ISP PAN, „Biuletyn Analiz i Opinii” 2017, nr 04.

Framework agreement between the European Union and Australia, dostępna w internecie [dostęp 11 XII 2020]: <https://www.dfat.gov.au/geo/europe/european-union/ Pages/australia-european-union-eu-framework-agreement $\rangle$.

Global Britain in a competitive age. The Integrated Review of Security, Defence, Development and Foreign Security, HM Government, March 2021, dostępny w internecie [dostęp: 14 IV 2021]: 〈https://www.gov.uk〉.

Hamilton D. S., US and EU Perspectives on their own dense, yet non-existent "Strategic Partnership", [w:] Strategic partnership as an instrument of EU foreign policy, Workshop Report, November 2015, dostępny w internecie [dostęp: 11 XII 2020]: <http://www.thomasrenard.eu/uploads/6/3/5/8/6358199/strategic-partnership-workshop-report-final.pdf $\rangle$.

Hillion Ch., Adaptation for autonomy? Candidates for EU membership and the CFSP, "Global Affairs" 2017, vol. 3, issue 3.

Japan-EU strategic partnership agreement, dostępna $\mathrm{w}$ internecie [dostęp: 10 XII 2020]: 〈https://www.mofa.go.jp/erp/ep/page22e_000707.html〉.

Johnson B., Przemowa na Konferencji Bezpieczeństwa w Monachium 19 lutego 2021 r., dostępna w internecie [dostęp: 14 IV 2021]: <https://www.gov.uk/government/speeches/prime-ministers-speech-at-the-munich-security-conference-19february-2021>.

Komunikat prasowy Komisji Europejskiej z 24 grudnia 2020 roku, dostępny w internecie [dostęp: 16 III 2021]: <https://ec.europa.eu/commission/presscorner/ detail/en/ip_20_2531>.

Lain S., Nouwens V., The consequences of brexit for european defence and security, April 2017, dostępny w internecie [dostęp: 2 II 2021]: <https://rusi.org/sites/default/ files/201704_o8_rusi-fes_brexit_defence_and_security_lain_and_nouwens.pdf $\rangle$.

Leckey T., Change of command ceremony held at Camp Butmir, European Union Force in $\mathrm{BiH}$, komunikat prasowy, 26 VI 2019, dostępny w internecie [dostęp: 10 XII 2020]: <http://www.euforbih.org/eufor/index.php/press-corner/ press-statements/2519-change-of-command-ceremony-at-camp-butmir $>$.

Lehne S., Rivals or partners? The EU-UK foreign policy relationship after brexit, Carnegie Europe, 30 III 2021, dostępny w internecie [dostęp: 30 III 2021]: <https://carnegieeurope.eu/2021/o3/30/rivals-or-partners-eu-uk-foreign-policyrelationship-after-brexit-pub-84197>.

Martill B., Hard bargaining dies hard; the cultural factors behind Britain's ill-suited Brexit negotiation strategy, LSE British Politics and Policy, 19 X 2020.

May T., Przemowa z 17 I 2017, dostępna w internecie [dostęp: 8 IV 2021]: <https:// time.com/4636141/theresa-may-brexit-speech-transcript/ $>$. 
May T., Przemowa na Konferencji Bezpieczeństwa w Monachium 17 II 2018, dostępna w internecie [dostęp: 10 XII 2020]: 〈https://www.gov.uk/government/ speeches/pm-speech-at-munich-security-conference-17-february-2018 $\rangle$.

May T., Przemowa na temat brexitu, 25 IV 2016, dostępna w internecie [dostęp: 13 III 2021]: <http://www.conservativehome.com/parliament/2016/o4/theresa-mays-speech-on-Brexit-full-text.html $>$.

May T., The future relationship between the United Kingdom and the European Union, Policy paper, 12 VII 2018, dostępny w internecie [dostęp: 13 II 2021]: <https:// www.gov.uk/government/publications/the-future-relationship-between-theunited-kingdom-and-the-european-union>.

Naert F., The use of the CFSP legal basis for EU international agreements in combination with other legal bases, [w:] The EU as a global actor - bridging legal theory and practic, eds J. Czuczai, F. Naert, Brill NV 2017.

Norway and the EU - partners for Europe, Norwegian Ministry of Foreign Affairs, s. 14, dostępny w internecie [dostęp: 15 XII 2020]: <www.regjeringen.no/ globalassets/departementene/ud/vedleggeuropapolitikk/Norway_eu.pdf $>$.

Norway and the EU. Mission of Norway to the EU, dostępny w internecie [dostęp: 11 XII 2020]: 〈www.norway.no〉.

Notice concerning the provisional application of the Strategic Partnership Agreement between the European Union and its Member States of the one part and Canada of the other part, Dz.U. UE (2017/L89/60) 1 IV 2017 roku, dostępny w internecie [dostęp: 10 XII 2020]: <https://www.consilium.europa.eu/en/documents-publications/ treaties-agreements/agreement $/$ ? $\mathrm{id}=2016018$ \&DocLanguage $=\mathrm{en} \#\rangle$.

Oleksiejuk M., The impacts of Brexit on the security and the defence industry in the European Union and the United Kingdom, 21 IV 2020, dostępny w internecie [dostęp: 10 XII 2020]: <https://warsawinstitute.org/impactsbrexit-security-defence-industry-european-union-united-kingdom/ $>$.

Our approach to the Future Relationship with the EU, Prime Minister's Office, 27 II 2020, dostępny w internecie [dostęp: 11 XII 2020]: <https://www.gov.uk/government/ publications/our-approach-to-the-future-relationship-with-the-eu $\rangle$.

Pierwszy zarys Deklaracji Politycznej, dostępny w internecie [dostęp: 13 IV 2021]: $<$ https://ec.europa.eu/info/publications/outline-political-declaration-settingout-framework-future-relationship-between-european-union-and-unitedkingdom-great-britain-and-northern-ireland-agreed-negotiators-level-14-november-2018_hu>.

Porozumienie między Europejska Wspólnota Energii Atomowej (EURATOM) i Zjednoczonym Królestwem o cywilnej współpracy przy bezpiecznym i pokojowym użyciu energiii atomowej, dostępne w internecie [dostęp: 30 XII 2020]: https:// ec/europe.eu/info/files/eu-uk-civil-nuclear-agreement_en>.

Porozumienie między Unia Europejska a Zjednoczonym Królestwem dotyczacego procedur bezpieczeństwa dla wymiany i ochrony informacji niejawnych, dostępne w internecie [dostęp: 30 XII 2020]: <https:///ec.europa.eu/info/files/ eu-uk-security-information-agreement_en $\rangle$. 
Post-Brexit UK won't use EU Galileo satellite system, British PM says, 1 XII 2018, dostępny w internecie [dostęp: 10 XII 2020]: 〈https://www.dw.com/en/post-brexituk-wont-use-eu-galileo-satellite-system-british-pm-says/a-46533333 >.

Raab D., Global Britain is leading the world as a force for good, "Sunday Telegraph", 23 IX 2019, dostępny w internecie [dostęp: 9 XII 2020]: 〈www.gov.uk〉.

Relations with the United Kingdom, European Commission, dostępny w internecie [dostęp: 10 XII 2020]: https://ec.europa.eu/info/european-union-and-unitedkingdom-forging-newpartnership/future-partnership/negotiation-roundsfuture-partnership-betweeneuropean-union-and-united-kingdom_en>.

Revised Political Declaration setting the framework for the future relationship between the European Union and the United Kingdom, Official Journal of the European Union (2020/C 34/01), 31 I 2020.

Shea J., European defence after brexit. A plus or a minus? "European View" 2020, vol. 19, issue 1 .

Statement by Michel Barnier, following Round 4 of negotiations for a new partnership between the European Union and the United Kingdom, 5 VI 2020, dostępny w internecie [dostęp: 9 XII 2020]: <https://ec.europa.eu/commission/ presscorner/detail/en/speech_20_1017>.

Tardy T., CSDP: getting third states on board, European Union Institute for Security Studies, 7 III 2014 [dostęp: 13 XII 2020], dostępny w internecie: <https://www. iss.europa.eu/content/csdp-getting-third-states-board $>$.

Task Force (S. Abrial, P. Westmacott $\mathrm{i}$ in.), Toward a future EU-UK relationship in foreign policy and defense, Atlantic Council Europe Center Report, February 2021.

Traktat o Unii Europejskiej (wersja skonsolidowana), opublikowany w Dz.U. UE (2016/c202/13) z 7 czerwca 2016 roku, dostępny w internecie [dostęp: 13 XII 2020]: <https://eur-lex.europa.eu/resource.html?uri=cellar:9e8d52e12c70-11e6-b497-01aa75ed71a1.0018.01/Doc_2\&format=PDF $>$.

UK defence personnel statistics briefing paper, House of Commons Library, 8 III 2021 [dostęp: 20 III 2021], dostępny w internecie: <https://commonslibrary.parliament.uk/research-briefings/cbp-7930/>.

Umowa o Europejskim Obszarze Gospodarczym. Dz.U. (L1) z 3 stycznia 1994 z późn. zm., dostępny w internecie [dostęp: 15 XII 2020]: <http://www.efta. int?Legal-Text/EEA-Agreement-1327>.

Umowa o wystąpieniu Zjednoczonego Królestwa Wielkiej Brytanii i Irlandii Północnej z Unii Europejskiej i Europejskiej Wspólnoty Energii Atomowej, Dz.U. UE (2019/C 384 I/1), 12 XI 2019.

Unijna wspótpraca obronna: Rada określa warunki uczestnictwa państw trzecich $w$ PESCO, komunikat prasowy, 5 XI 2020, dostępny w internecie [dostęp: 13 XII 2020]: <https://www.consilium.europa.eu/pl?press/press-releases?2020/ 11/o5/eu-defence-cooperation $>$.

What is not covered by the EEA Agreement, EFTA, dostępny w internecie [dostęp: 15 XII 2020]: 〈https://www.efta.int/eea/eea-agreement/eea-basic-features>. 
Whitman R. G., Missing in action: The EU-UK foreign, security and defence policy relationship after Brexit, Wilfired Martens Centre for European Studies, "European View" 2020, vol. 19(2).

Wintour P., Boffey D., UK insists it will not grant EU ambassador full diplomatic status, "The Guardian" [online], 21 I 2021, [dostęp: 1 II 2021], dostępny w internecie: <https://www.theguardian.com/world/2021/jan/21/ uk-insists-it-will-not-grant-eu-ambassador-full-diplomatic-status $>$.

Wither J.K., A secure Brexit? UK security and defense and the decision to leave the European Union, George C.Marshall European Center For Security Studies, "Security Insights" 2017, no. 18, dostępny w internecie [dostęp: 13 III 2021]: <https://www.marshallcenter.org/sites/default/files/files/2019-10/ SecurityInsights_18.pdf $>$.

Wright G., UK-EU future relationship. Defence and security cooperation, The Institute for Government, February 2020.

Wystąpienie Michela Barniera w EU Institute for Security Studies w maju 2018 roku, dostępne w internecie [dostęp: 15 XII 2020]: <https:/europa.eu/ rapid/press-release_SPEECH-18-3785_en.htm>.

Wytyczne Rady Europejskiej (art. 50) w sprawie ram przyszłych stosunków UEWielka Brytania, Dokument nr. EUCO XT 20001/18 z 23 marca 2018 roku, dostępny w internecie [dostęp: 13 grudnia 2020]: 〈www.consilium.europa.eu〉.

Zięba R., Teoria Bezpieczeństwa, [w:] Teorie i podejścia badawcze w nauce o stosunkach międzynarodowych, red. R. Zięba, S. Bieleń, J. Zając, Wydawnictwo Wydziału Dziennikarstwa i Nauk Politycznych Uniwersytetu Warszawskiego, Warszawa 2015.

Zięba R., The Euro-Atlantic security system in the $21^{\text {st }}$ century. From cooperation to crisis, Springer International Publishing, New York 2018, (Global Power Shift). 